\title{
Molecular Characteristics and Formation Mechanisms of Biogenic Secondary Organic Aerosols in the Summer Atmosphere at Mt. Tai on the North China Plain
}

\author{
Yanan Yi', Jingjing Meng ${ }^{1,2^{*}}$, Zhanfang Hou ${ }^{1,2^{*}}$, Li Yan ${ }^{3}$, Xiaodi Liu ${ }^{1}$, Mengxuan Fu', \\ Zheng Li ${ }^{1}$, Ruiwen Zhou ${ }^{1}$, Yachen Wang ${ }^{1}$, Benjie Wei ${ }^{1}$ \\ ${ }^{I}$ School of Environment and Planning, Liaocheng University, Liaocheng 252000, China \\ 2 State Key Laboratory of Loess and Quaternary Geology, Key Lab of Aerosol Chemistry and Physics, Institute of Earth \\ Environment, Chinese Academy of Sciences, Xi'an 710075, China \\ ${ }^{3}$ Chinese Academy for Environmental Planning, Beijing 100012, China
}

\begin{abstract}
To investigate the molecular characteristics and formation mechanisms of biogenic secondary organic aerosol (BSOA), daytime and nighttime $\mathrm{PM}_{2.5}$ samples were collected at the summit of Mt. Tai during the summer of 2016. The critical indicators of primary sources, such as elemental carbon (EC) and levoglucosan, displayed similar values during the daytime and nighttime, suggesting that changes in the boundary layer heights (BLHs) produced only inconsequential effects during the observation campaign. The molecular distributions of the BSOA were dominated by isoprene SOA tracers $(68.5 \pm$ $\left.42.6 \mathrm{ng} \mathrm{m}^{-3}\right)$, followed by monoterpene $\left(43.5 \pm 24.4 \mathrm{ng} \mathrm{m}^{-3}\right)$ and $\beta$-caryophyllene $\left(16.3 \pm 8.6 \mathrm{ng} \mathrm{m}^{-3}\right) \mathrm{SOA}$ tracers. Due to the higher diurnal temperatures and solar radiation, the concentrations of all of the tracers were higher during the day than at night. The ratio of the combined cis-pinonic and cis-pinic acid to the MBTCA (P/M) was much lower than in Chinese cities and at the Tibetan background site, indicating that the monoterpene SOA was relatively aged in the mountainous atmosphere, in large part because of the stronger solar radiation at the peak of Mt. Tai. The concentrations of the BSOA products exhibited a significantly positive correlation with the level of ozone during the daytime $\left(R^{2}=0.58-0.86\right)$ and the temperature over the whole sampling period $\left(R^{2}=0.37-0.75\right)$, as higher temperatures can accelerate the emission of biogenic volatile organic compounds and the formation of SOA. By contrast, the BSOA tracers displayed a negative linear correlation with the relative humidity $(\mathrm{RH})\left(R^{2}=0.43-0.84\right)$ and the in situ particle $\mathrm{pH}\left(\mathrm{pH}_{\mathrm{is}}\right)\left(R^{2}=0.55-0.70\right)$ because high $\mathrm{RH}$ can inhibit the acid-catalyzed formation of BSOA due to the dilution of the aerosol acidity. No correlation between the BSOA tracers and anthropogenic pollutants (e.g., levoglucosan, $\mathrm{SO}_{4}{ }^{2-}, \mathrm{NO}_{3}{ }^{-}$and $\mathrm{EC}$ ) was observed during the daytime or nighttime, suggesting that BSOA tracers in the atmosphere of Mt. Tai during summer were primarily derived from the local oxidation of BVOCs rather than long-distance-transported anthropogenic emissions from the lowlands.
\end{abstract}

Keywords: Biogenic secondary organic aerosol (BSOA); Isoprene; Aerosol acidity; Temperature and relative humidity; Anthropogenic pollutants.

\section{INTRODUCTION}

Terrestrial vegetation can release plenty of biogenic volatile organic compounds (BVOCs) into the atmosphere, including isoprene, monoterpenes and sesquiterpenes (Kesselmeier and Staudt, 1999). Emissions of BVOCs $\left(1150 \mathrm{Tg}^{-1}\right)$ in the global atmosphere are one order of magnitude higher than anthropogenic VOCs (AVOCs), which can significantly increase the concentration levels of secondary organic aerosols (SOA) (Guenther et al., 2006; Li et al., 2013a). SOA are

\footnotetext{
${ }^{*}$ Corresponding author.

E-mail address: mengjingjing@lcu.edu.cn (J. Meng); houzhanfang@lcu.edu.cn (Z.Hou)
}

produced by the oxidation of VOCs with oxidants such as ozone $\left(\mathrm{O}_{3}\right)$, hydroxyl radical $(\mathrm{OH})$ and nitrate radical $\left(\mathrm{NO}_{3}\right)$, which can affect the atmosphere radiation directly by absorbing and scattering sunlight and indirectly acting as a cloud condensation nuclei (CCN) (Li et al., 2013a; Han et al., 2014; Hu et al., 2018). SOA play an important role in atmospheric visibility, air quality, climate change and human health (Han et al., 2014; Huang et al., 2014; Haque et al., 2016; Zhu et al., 2016; An et al., 2019).

As the oxidation products of BVOCs, biogenic SOA (BSOA) derived from terrestrial ecosystems are polar and hygroscopic (Han et al., 2014; Haque et al., 2016). Claeys et al. (2004) discovered that the oxidation production of isoprene, 2-methyltetrols and 2-methylglyceric have a great influence on the formation of BSOA. As the predominant precursors of $\mathrm{BSOA}$, isoprene and monoterpenes account 
for around $50 \%$ and $10 \%$ of the earth's BVOCs, respectively (Zhu et al., 2016). Investigations on the BSOA tracers of isoprene, monoterpenes and $\beta$-caryophyllinic acid have been performed in various environments such as urban (Ren et al., 2018; Zhu et al., 2018a), forested (Ren et al., 2019) and continental background regions (Li et al., 2013b), most of which have been conducted on the ground surface. Compared to the lowland areas, the atmospheric environment of highaltitude regions can provide a unique and ideal situation for the study of SOA due to stronger sunlight, lower temperatures and higher humidity (Li et al., 2013a). Measurement over the high-elevation mountain regions is an alternative research method for high-altitude aerosol characterization, which has such advantage as low cost and long-term sampling compared to aircraft and balloon-based observations (Meng et al., 2014). Mt. Tai is located in the center part of the North China Plain, one of the most heavily polluted areas in the world (Meng et al., 2018). Moreover, the North China Plain is one of the regions with the highest emissions of VOCs in China (Zhu et al., 2018b). In the past decades, a few studies have been performed to investigate the molecular characteristics and the sources of BSOA tracers and evaluate the effect of anthropogenic pollutants from long-range transport on the formation mechanisms of SOA at Mt. Tai (Fu et al., 2010; Zhu et al., 2017). However, most of the studies were conducted during May and June when the effect of anthropogenic activities such as biomass burning (burning of wheat straw) was significant (Fu et al., 2010; Zhu et al., 2017), whereas information on BSOA at the summit of Mt. Tai in the typical summertime season (i.e., July) is very limited when the emission of BVOCs is dominant. Thus, it is essential to elucidate the molecular distributions and formation mechanisms of BSOA in the alpine atmosphere, especially when the biogenic emission is dominant in the summer.
To better investigate the molecular distributions, sources and formation mechanisms of BSOA tracers over the highelevation remote regions, we collected $\mathrm{PM}_{2.5}$ samples at the summit of Mt. Tai and conducted measurements of SOA tracers of isoprene, monoterpenes and $\beta$-caryophyllene along with organic carbon (OC), elemental carbon (EC), water soluble organic carbon (WSOC) and inorganic ions. Here, we report the diurnal variations in concentration levels, molecular characteristics and sources of BSOA tracers at Mt. Tai and then investigate the impact of meteorological factors (e.g., $\mathrm{O}_{3}$, relative humidity and temperature), particle acidity $\left(\mathrm{pH}_{\mathrm{is}}\right.$ ), liquid water content (LWC) and anthropogenic pollutants (e.g., levoglucosan, $\mathrm{SO}_{4}{ }^{2-}, \mathrm{NO}_{3}{ }^{-}$and $\mathrm{EC}$ ) on the formation mechanisms of BSOA tracers.

\section{MATERIALS AND METHODS}

\section{Aerosol Sampling}

Mt. Tai $\left(36^{\circ} 15^{\prime} \mathrm{N}, 117^{\circ} 6^{\prime} \mathrm{E}\right.$; $1534 \mathrm{~m}$ a.s.l.; Fig. 1) is located in the North China Plain, where almost $80 \%$ of the mountainous land is covered by 989 species of vegetation (Fu et al., 2010). The detailed information of sampling site has been reported in our previous study (Meng et al., 2018). In the current work, $\mathrm{PM}_{2.5}$ samples were collected from 1 July to 26 July and each sample lasted for $12 \mathrm{~h}$ on a day/night basis. $\mathrm{PM}_{2.5}$ samples were collected using a medium-volume air sampler (KC-120H; Qingdao Laoshan Company, China) at an airflow rate of 100 $\mathrm{L} \mathrm{min}^{-1}$. The daytime samples were collected from 07:00 to 18:50 and the nighttime samples were collected from 19:00 to 6:50 of the next day, respectively. A total of $52 \mathrm{PM}_{2.5}$ samples (26 for daytime and 26 for nighttime) and two blank samples were collected in this study. The blank samples were collected by mounting the blank filter onto the sampler for $10 \mathrm{~min}$ without sucking

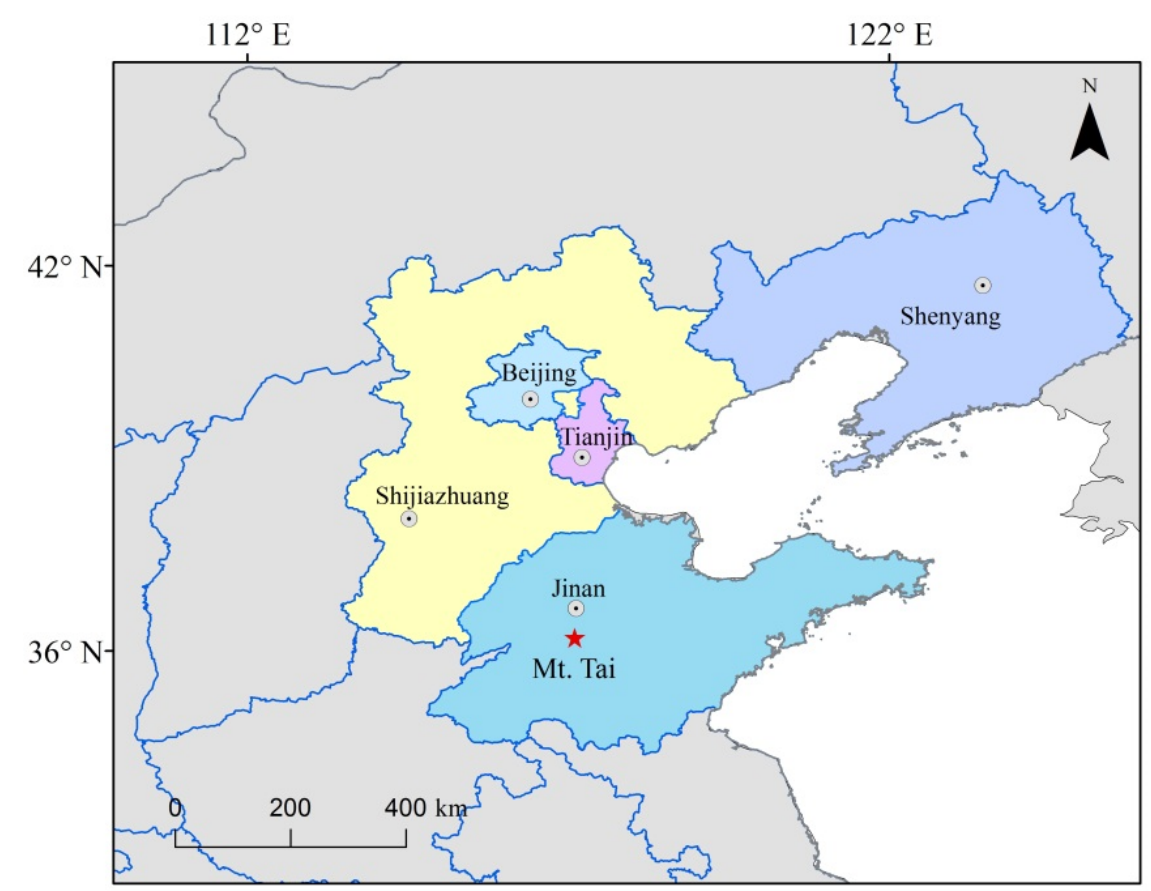

Fig. 1. Map showing the location of the sampling site (Mt. Tai; $36^{\circ} 15^{\prime} \mathrm{N}, 117^{\circ} 6^{\prime} \mathrm{E} ; 1534 \mathrm{~m}$ a.s.1.). 
any air. Before the collection, all samples were placed in prebaked ( $450^{\circ}$ for $8 \mathrm{~h}$ ) quartz fiber (Grade 42 ; Whatman, USA). After the collection, all $\mathrm{PM}_{2.5}$ samples were sealed in an aluminum bag and stored at $-20^{\circ} \mathrm{C}$ prior to analysis. In addition, the ozone concentration was synchronously measured in situ using a UV absorption analyzer (Model 49C; Thermo Electron Corporation).

\section{Chemical Analysis}

Detailed methods for extraction and derivatization were described in previous studies (Wang and Kiawamura, 2006; Wang et al., 2009). Briefly, one fourth of filter was cut into pieces and extracted with a mixture of dichloromethane and methanol $(2: 1, v / v)$ under sonication three times each for $15 \mathrm{~min}$. The extracts were concentrated by a rotary evaporator under vacuum and then the filtrate was dried using pure nitrogen stream. After derivatization with a mixture $(60 \mu \mathrm{L})$ of $\mathrm{N}, \mathrm{O}$-bis-(trimethylsilyl) trifluoroacetamide (BSTFA) and pyridine $(5: 1, v / v)$ at $70^{\circ} \mathrm{C}$ for $3 \mathrm{~h}$, the extracts were diluted with $n$-hexane prior to GC-MS determination. The details of using GC-MS have been described elsewhere (Li et al., 2013a).

All the target compounds were quantified using the peak area of the individual characteristic ion. For the quantification of cis-pinic acid and cis-pinonic acid (PA), their GC-MS response factors were determined using authentic standards. GC-MS response factors of two 2-methyltetrols (2methylthreitol and 2-methylerythritol), three $\mathrm{C}_{5}$-alkene triols (cis-2-methyl-1,3,4-trihydroxy-1-butene, 3-methyl2,3,4-trihydroxy-1-butene and trans-2-methyl-1,3,4trihydroxy-1-butene) were replaced using erythritol. And 2methylglyceric acid (2-MG), 3-hydroxyglutaric acid (3HGA), 3-methyl-1,2,3-butanetricarboxylic acid (MBTCA) and $\beta$-caryophyllinic acid were replaced using the response factors of glyceric acid, tartaric acid, suberic acid and cispinic acid, respectively (Li et al., 2013a; Ren et al., 2019). Method detection limits (MDLs) for major compounds, that is, cis-pinic acid, 2-methylthreitol, 3-methyl-2,3,4-trihydroxy1-butene, 2-MG, 3-HGA and $\beta$-caryophyllinic acid, were $0.04,0.03,0.08,0.12,0.05$ and $0.15 \mathrm{ng} \mathrm{m}^{-3}$, respectively. The target compounds in the blank filters were detected to be very low $(<3 \%)$. The recoveries of all the target compounds ranged from $86 \%$ to $110 \%$. Therefore, data published in this study were corrected for both field blanks and recoveries.

Detailed methods for the analysis of elemental carbon (EC), organic carbon (OC), water-soluble organic carbon (WSOC) and inorganic ions in $\mathrm{PM}_{2.5}$ samples were described elsewhere (Meng et al., 2018). Briefly, EC and OC in aerosols were detected by the DRI Model 2001 Carbon Analyzer following the Interagency Monitoring of Protected Visual Environments (IMPROVE) thermal/optical reflectance (TOR) protocol (Chow et al., 2004). WSOC and inorganic ions were determined using a Total Carbon Analyzer (TOC-L CPH; Shimadzu, Japan) and an ion chromatography (Dionex 600; Dionex, USA), respectively. In this study, aerosol liquid water content (LWC) and particle in situ $\mathrm{pH}\left(\mathrm{pH}_{\mathrm{is}}\right)$ were calculated by the Aerosol Inorganic Model (AIM) using a $\mathrm{SO}_{4}{ }^{2-}-\mathrm{NO}_{3}{ }^{-}-\mathrm{NH}_{4}{ }^{+}-\mathrm{H}^{+}$system (AIM-II; http://www.aim.env. uea.ac.uk/aim/aim.php) (Li et al., 2013a).

\section{RESULTS AND DISCUSSION}

\section{Diurnal Variations of Major Chemical Components of PM2.5}

The diurnal variations of main chemical components including OC, EC, WSOC and water-soluble inorganic ions in the atmosphere of Mt. Tai were summarized in Table 1 and Fig. 2 along with meteorological parameters. As a key marker of primary combustion source (Verma et al., 2017), the EC concentration was pretty small $\left(0.40 \pm 0.15 \mu \mathrm{g} \mathrm{m}^{-3}\right)$ and presented similar value during the daytime and nighttime $(p>0.05)$ (Table 1), suggesting that the effect of both the changes in the boundary layer heights (BLHs) and the anthropogenic pollutants from long-range transport was minor. The daytime concentrations of OC and WSOC were higher than those in the nighttime, and the daytime ratios of OC/EC and WSOC/OC were also about 1.5 times higher than at night (Table 1). These comparisons suggested that the photochemical oxidation was much stronger in the daytime because of the stronger solar irradiation and higher temperature (Hegde and Kawamura, 2012; Meng et al., 2018). As a significant tracer for biomass burning (Liu et al., 2019), levoglucosan concentration was $22.0 \pm 18.0 \mathrm{ng} \mathrm{m}^{-3}$, which was 20 times lower than that in the biomass-burning period of 2006 (May-June: $425 \mathrm{ng} \mathrm{m}^{-3}$ (Fu et al., 2008); early June: $403 \mathrm{ng} \mathrm{m}^{-3}$ (Fu et al., 2012)) at Mt. Tai. Moreover, $\mathrm{EC}, \mathrm{OC}$ and WSOC did not exhibit any correlation with levoglucosan at Mt. Tai, suggesting the insignificant impact of biomass burning on the mountainous aerosol during the sampling period.

As shown in Table 1 and Fig. 2, $\mathrm{SO}_{4}{ }^{2-}$ was observed to be the most abundant inorganic ion, followed by $\mathrm{NO}_{3}^{-}$and $\mathrm{NH}_{4}{ }^{+}$throughout the whole sampling period. The daytime concentration and relative abundance of $\mathrm{SO}_{4}{ }^{2-}$ were larger than at night (Table 1 and Fig. 2), largely because the higher temperature and humidity in the daytime can promote the formation of $\mathrm{SO}_{4}{ }^{2-}$ from the oxidation of $\mathrm{SO}_{2}$ in the aqueous phase (Fang et al., 2017; Jiang et al., 2017; Wu et al., 2017). In contrast, the smaller concentrations and relative abundances of $\mathrm{NO}_{3}{ }^{-}$and $\mathrm{NH}_{4}{ }^{+}$were observed during the daytime than during the nighttime (Table 1 and Fig. 2), mainly being attributed to the enhanced volatility of $\mathrm{NH}_{4} \mathrm{NO}_{3}$ at the higher temperature in daytime (Meng et al., 2016; Li et al., 2018b; Priyadharshini et al., 2019). The remaining five kinds of inorganic ions including $\mathrm{K}^{+}, \mathrm{Na}^{+}$, $\mathrm{Ca}^{2+}, \mathrm{Mg}^{2+}$ and $\mathrm{Cl}^{-}$accounted for relatively small fraction (5.7\%) of $\mathrm{PM}_{2.5}$ mass. As the important indicators of primary sources, $\mathrm{K}^{+}, \mathrm{Na}^{+}, \mathrm{Ca}^{2+}, \mathrm{Mg}^{2+}$ and $\mathrm{Cl}^{-}$did not present significant diurnal variations $(p>0.05)$ (Table 1$)$, again suggesting that the impact of BLHs was inessential on the aerosols of Mt. Tai.

In this study, $\mathrm{pH}_{\text {is }}$ and LWC were calculated by the AIMII model. Previous studies have demonstrated that LWC is determined by anthropogenic inorganic salts and RH (Meng et al., 2018; Ren et al., 2018). The total concentration of $\mathrm{SO}_{4}{ }^{2-}, \mathrm{NO}_{3}{ }^{-}$and $\mathrm{NH}_{4}{ }^{+}$in daytime $\left(32.8 \pm 17.8 \mu \mathrm{g} \mathrm{m}^{-3}\right)$ was nearly equal to that in nighttime $\left(33.2 \pm 14.4 \mu \mathrm{g} \mathrm{m}^{-3}\right)$, but the daytime RH $(77.5 \pm 4.7 \%)$ was much lower than that during nighttime $(89.2 \pm 4.4 \%)$. Thus, the daytime LWC 
Table 1. Meteorological factors and concentrations of inorganic ions, ozone, carbonaceous compounds, in situ $\mathrm{pH}\left(\mathrm{pH}_{\mathrm{is}}\right)$ and liquid water content (LWC) in $\mathrm{PM}_{2.5}$ samples in Mt. Tai during the sampling time.

\begin{tabular}{lllll}
\hline & Daytime $(n=26)$ & Nighttime $(n=26)$ & Total $(n=52)$ & $p$-value $(t$-test $)$ \\
\hline Inorganic ions $\left(\mu \mathrm{g} \mathrm{m}^{-3}\right)$ & & & & \\
$\mathrm{SO}_{4}{ }^{2-}$ & $20.2 \pm 10.4$ & $14.7 \pm 5.8$ & $17.5 \pm 8.8$ & 0.003 \\
$\mathrm{NO}_{3}{ }^{-}$ & $4.6 \pm 3.2$ & $7.3 \pm 4.0$ & $6.0 \pm 3.8$ & 0.038 \\
$\mathrm{NH}_{4}{ }^{+}$ & $8.1 \pm 4.2$ & $11.1 \pm 4.3$ & $9.6 \pm 4.5$ & 0.001 \\
$\mathrm{Na}^{+}$ & $0.5 \pm 0.2$ & $0.5 \pm 0.3$ & $0.5 \pm 0.3$ & 0.742 \\
$\mathrm{~K}^{+}$ & $0.6 \pm 0.2$ & $0.6 \pm 0.3$ & $0.6 \pm 0.2$ & 0.257 \\
$\mathrm{Ca}^{2+}$ & $0.4 \pm 0.2$ & $0.4 \pm 0.3$ & $0.4 \pm 0.2$ & 0.314 \\
$\mathrm{Mg}^{2+}$ & $0.2 \pm 0.1$ & $0.3 \pm 0.1$ & $0.3 \pm 0.1$ & 0.138 \\
$\mathrm{Cl}^{-}$ & $0.4 \pm 0.2$ & $0.4 \pm 0.1$ & $0.4 \pm 0.1$ & 0.132 \\
Meteorological parameters and ozone & $21.4 \pm 2.5$ & $12.2 \pm 2.3$ & & \\
$\mathrm{~T}\left({ }^{\circ} \mathrm{C}\right)$ & $77.5 \pm 4.7$ & $89.2 \pm 4.4$ & $16.8 \pm 5.2$ & 0.035 \\
$\mathrm{RH}(\%)$ & $28.5 \pm 16.9$ & $17.2 \pm 9.5$ & $83.3 \pm 7.4$ & 0.002 \\
$\mathrm{O}_{3}($ ppb) & $3.6 \pm 1.3$ & $2.1 \pm 0.3$ & $2.9 \pm 14.7$ & 0.118 \\
Other species $\left(\mu \mathrm{g} \mathrm{m}^{-3}\right)$ & $0.40 \pm 0.16$ & $0.40 \pm 0.14$ & $2.8 \pm 1.2$ & 0.132 \\
$\mathrm{OC}$ & $2.3 \pm 0.9$ & $0.9 \pm 0.3$ & $0.40 \pm 0.15$ & 0.534 \\
$\mathrm{EC}$ & $0.6 \pm 0.1$ & $0.4 \pm 0.1$ & $1.6 \pm 1.0$ & 0.019 \\
$\mathrm{WSOC}$ & $9.3 \pm 2.7$ & $5.9 \pm 1.9$ & $0.5 \pm 0.1$ & 0.500 \\
$\mathrm{WSOC} / \mathrm{OC}$ & $-0.1 \pm 0.3$ & $1.6 \pm 0.5$ & $7.6 \pm 2.9$ & 0.901 \\
OC/EC & $17.0 \pm 10.2$ & $24.9 \pm 14.3$ & $0.7 \pm 1.0$ & 0.017 \\
$\mathrm{pH}$ is & $21.9 \pm 18.2$ & $22 \pm 18.1$ & $20.9 \pm 12.9$ & 0.039 \\
$\mathrm{LWC}$ & $45.8 \pm 19.2$ & $43.8 \pm 14.2$ & $22.0 \pm 18.0$ & 0.822 \\
Levoglucosan $\left(\mathrm{ng} \mathrm{m}^{-3}\right)$ & & $44.8 \pm 16.7$ & 0.003 \\
$\mathrm{PM}{ }_{2.5}$ & &
\end{tabular}
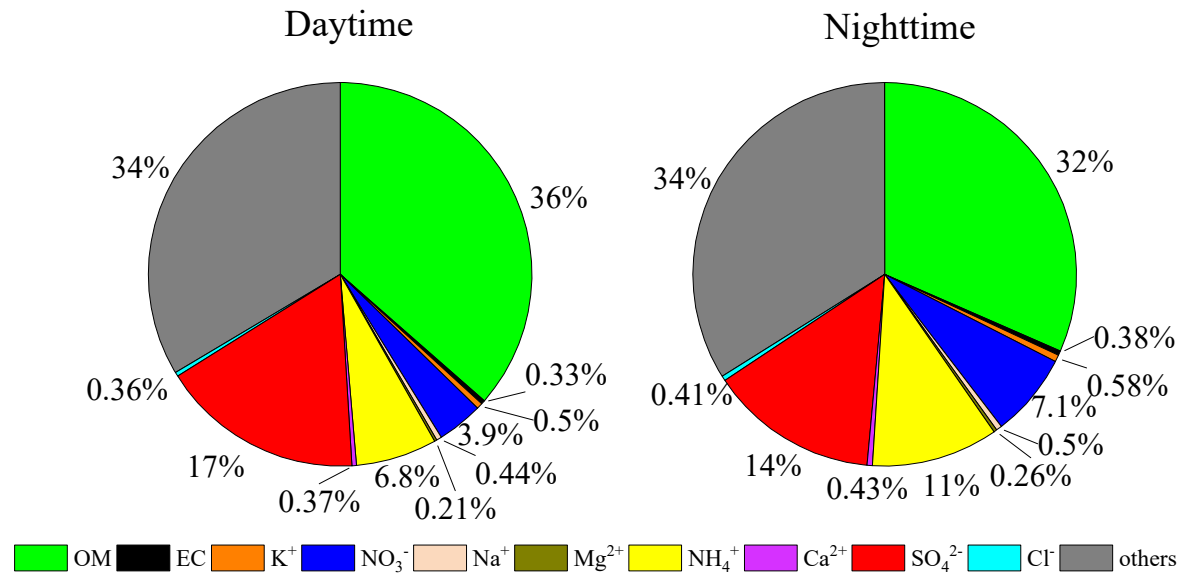

Fig. 2. Chemical composition of $\mathrm{PM}_{2.5}$ during daytime and nighttime in Mt. Tai.

$\left(17.0 \pm 10.2 \mu \mathrm{g} \mathrm{m}^{-3}\right)$ was lower than that at night $(24.9 \pm$ $14.3 \mu \mathrm{g} \mathrm{m}^{-3}$ ) (Table 1). However, $\mathrm{pH}_{\text {is }}$ exhibited an opposite diurnal variation pattern to the concentration of LWC (Table 1), suggesting that the aerosols were more acidic on the top of Mt. Tai in daytime.

\section{Diurnal Characteristics of BSOA Tracers}

Isoprene SOA Tracers

Six kinds of isoprene SOA tracers quantified in the $\mathrm{PM}_{2.5}$ samples of Mt. Tai were summarized in Table 2 during the summertime. The total concentrations of isoprene SOA tracers during daytime $\left(71.6 \pm 46.2 \mathrm{ng} \mathrm{m}^{-3}\right)$ were higher than those during nighttime $\left(65.4 \pm 39.4 \mathrm{ng} \mathrm{m}^{-3}\right)$, largely because the stronger solar radiation and higher temperature conditions in daytime can accelerate the emission of biogenic VOCs and the production of SOA (Yuan et al., 2018).

As shown in Table 2 and Fig. 4, 2-methyltetrols (25.2 \pm $16.4 \mathrm{ng} \mathrm{m}^{-3}$ ) were the most abundant isoprene SOA tracers in the aerosols of Mt. Tai and accounted for $19.6 \%$ of the total BSOA tracers, followed by $\mathrm{C}_{5}$-alkene triols $(18.8 \%)$ and 2-methylglyceric acid (15.0\%). As shown in Fig. 4, 2methylthreitol correlated strongly with 2-methylerythritol during the daytime $\left(R^{2}=0.98\right)$ and nighttime $\left(R^{2}=0.80\right)$, respectively. Such a phenomenon was also observed in Chinese cities and the background site of Qinghai Lake (Ren et al., 2018), indicating that 2-methylthreitol and 2methylerythritol experienced the similar formation pathways. Surratt et al. (2006) have pointed out that both $\mathrm{C}_{5}$-alkene 
Table 2. Diurnal concentrations $\left(\mathrm{ng} \mathrm{m}^{-3}\right)$ of biogenic secondary organic aerosols in $\mathrm{PM}_{2.5}$ during summer in Mt. Tai.

\begin{tabular}{|c|c|c|c|c|}
\hline Compounds & Daytime $(n=28)$ & Nighttime $(n=29)$ & Total $(n=57)$ & $p$-value $(t$-test $)$ \\
\hline \multicolumn{5}{|l|}{ Isoprene SOA tracers } \\
\hline 2-methylglyceric acid & $20.4 \pm 10.2$ & $18 \pm 9.1$ & $19.2 \pm 9.6$ & 0.266 \\
\hline $\mathrm{C}_{5}$-alkene triols ${ }^{a}$ & $25.3 \pm 21.3$ & $23 \pm 17.8$ & $24.1 \pm 19.5$ & 0.000 \\
\hline 2-methyltetrols ${ }^{b}$ & $25.9 \pm 17.3$ & $24.5 \pm 15.7$ & $25.2 \pm 16.4$ & 0.026 \\
\hline Subtotal & $71.6 \pm 46.2$ & $65.4 \pm 39.4$ & $68.5 \pm 42.6$ & 0.005 \\
\hline \multicolumn{5}{|l|}{ Monoterpene SOA tracers } \\
\hline cis-pinonic acid & $7.7 \pm 4.7$ & $5.1 \pm 2.6$ & $6.4 \pm 4.0$ & 0.878 \\
\hline$c i s$-pinic acid & $2.5 \pm 1.7$ & $2.1 \pm 1.3$ & $2.3 \pm 1.5$ & 0.968 \\
\hline 3-hydroxyglutaric acid & $29.4 \pm 17.8$ & $25.5 \pm 16.4$ & $27.5 \pm 17.1$ & 0.185 \\
\hline $\mathrm{MBTCA}^{c}$ & $7.5 \pm 4.0$ & $7.2 \pm 4.7$ & $7.4 \pm 4.3$ & 0.279 \\
\hline Subtotal & $47.1 \pm 26.1$ & $40.0 \pm 22.6$ & $43.5 \pm 24.4$ & 0.280 \\
\hline \multicolumn{5}{|l|}{$\beta$-caryophyllene SOA tracers } \\
\hline$\beta$-caryophyllinic acid & $20.8 \pm 8.2$ & $11.7 \pm 6.3$ & $16.3 \pm 8.6$ & 0.048 \\
\hline Total tracers & $139.5 \pm 76.4$ & $117.1 \pm 64.4$ & $128.3 \pm 70.9$ & 0.041 \\
\hline
\end{tabular}

${ }^{a} \mathrm{C}_{5}$-alkene triols: the sum of cis-2-methyl-1,3,4-trihydroxy-1-butene, 3-methyl-2,3,4-trihydroxy-1-butene and trans-2methyl-1,3,4-trihydroxy-1-butene.

${ }^{b}$ 2-methyltetrols: the sum of 2-methylthreitol and 2-methylerythritol.

${ }^{c}$ MBTCA: 3-methyl-1,2,3-butanetricarboxylic acid.

triols and 2-methyltetrols are derived from chemical reactions of isoprene with $\mathrm{OH}$ radical under low- $\mathrm{NO}_{x}$ conditions. Therefore, $\mathrm{C}_{5}$-alkene triols exhibited a positive correlation with 2-methyltetrols throughout the whole sampling period $(R>0.6)$ (Fig. 5). Such a strong correlation was also observed in Shanghai, China (Ren et al., 2018), and high Arctic region (Fu et al., 2009). Chamber experiments and field observations have suggested that 2-methylglyceric acid is produced from the oxidation of isoprene under high- $\mathrm{NO}_{x}$ conditions and is promoted into the particle phase in the low humid atmosphere (Zhang et al., 2011; Li et al., 2013a; Ren et al., 2018). Therefore, the concentration of 2-methylglyceric acid was higher during daytime than that during nighttime due to the lower relative humidity in daytime (Table 1).

\section{Monoterpene SOA Tracers}

Four kinds of monoterpene SOA tracers, including cispinonic acid, cis-pinic acid, 3-hydroxyglutaric acid and MBTCA were determined in the $\mathrm{PM}_{2.5}$ samples of Mt. Tai (Table 2 and Fig. 4). The total concentrations of monoterpene SOA tracers in daytime $\left(47.1 \pm 26.1 \mathrm{ng} \mathrm{m}^{-3}\right)$ were around 1.2 times higher than those in nighttime $\left(40.0 \pm 22.6 \mathrm{ng} \mathrm{m}^{-3}\right)$, which was consistent with the diurnal variations of isoprene SOA tracers. Among the measured tracers of monoterpene oxidation products, 3-hydroxyglutaric acid was the dominant species and accounted for $63 \%$ and $64 \%$ of the total monoterpene SOA tracers during daytime and nighttime, respectively, followed by MBTCA (Table 2 and Fig. 3 ). The molecular distributions at Mt. Tai were also found in other regions such as oceans (Fu et al., 2011; Hu et al., 2013), mountains (Hong et al., 2019; Ren et al., 2019) and continents (Yuan et al., 2018). Previous studies have suggested that both cis-pinonic acid and cis-pinic acid can be further photodegraded into MBTCA (Szmigielski et al., 2007; Ding et al., 2012). Therefore, the ratio of $\mathrm{P} / \mathrm{M}$ (cis-pinonic acid plus cis-pinic acid to MBTCA) can be regarded as an indicator for organic aerosols aging (Szmigielski et al., 2007; Hu et al., 2008; Ding et al., 2011). The higher ratio of $\mathrm{P} / \mathrm{M}$ indicates the fresher monoterpene SOA, and the lower ratio reflects the older monoterpene SOA. Compared with that in nighttime, the smaller ratio of $\mathrm{P} / \mathrm{M}$ was observed in daytime, again suggesting that the daytime photochemical modification of aerosols is stronger because of the stronger solar radiation and the higher temperature. In this study, the average ratio of $\mathrm{P} / \mathrm{M}(1.45 \pm 0.88)$ at Mt. Tai was much lower than Chinese cities such as Xi'an (22.2), Shanghai (16.5), Chengdu (24.6), Guangzhou (19.9) and Urumqi (33.8) and Qinghai Lake (53.3) (Ren et al., 2018), a continental background site in the Tibetan Plateau during the summertime, suggesting that the monoterpene SOA were relatively aged in the mountainous atmosphere, largely due to the stronger solar radiation on the peak of Mt. Tai (Meng et al., 2018; Zhu et al., 2018a).

\section{$\beta$-Caryophyllene SOA Tracers}

Among a great deal of BVOCs determined to date, sesquiterpenes have been the least studied because of their low vapor pressure and high reactivity (Fu et al., 2009). However, sesquiterpenes might be the main source of SOA due to the high reactivity and aerosol yields (Fu et al., 2009; Ren et al., 2018). $\beta$-caryophyllene is one of the dominant sesquiterpenes, and most usually studied in various environments (Duhl et al., 2008; Xu et al., 2018; Zhu et al., $2018 \mathrm{a})$. $\beta$-caryophyllinic acid was produced either by the ozonolysis or photooxidation of $\beta$-caryophyllene (Jaoui et al., 2007; Yuan et al., 2018), which was measured in all $\mathrm{PM}_{2.5}$ samples of Mt. Tai. Being similar to the diurnal characteristics of isoprene and monoterpene SOA tracers, the concentration of $\beta$-caryophyllinic acid in daytime (20.8 \pm $8.2 \mathrm{ng} \mathrm{m}^{-3}$ ) was observed to be higher than that in nighttime $\left(11.7 \pm 6.3 \mathrm{ng} \mathrm{m}^{-3}\right)$ (Table 2 and Fig. 4).

\section{Comparison of BSOA Tracers with Previous Studies}

The concentrations of isoprene, monoterpene and $\beta$ caryophyllene oxidation products at Mt. Tai during the 


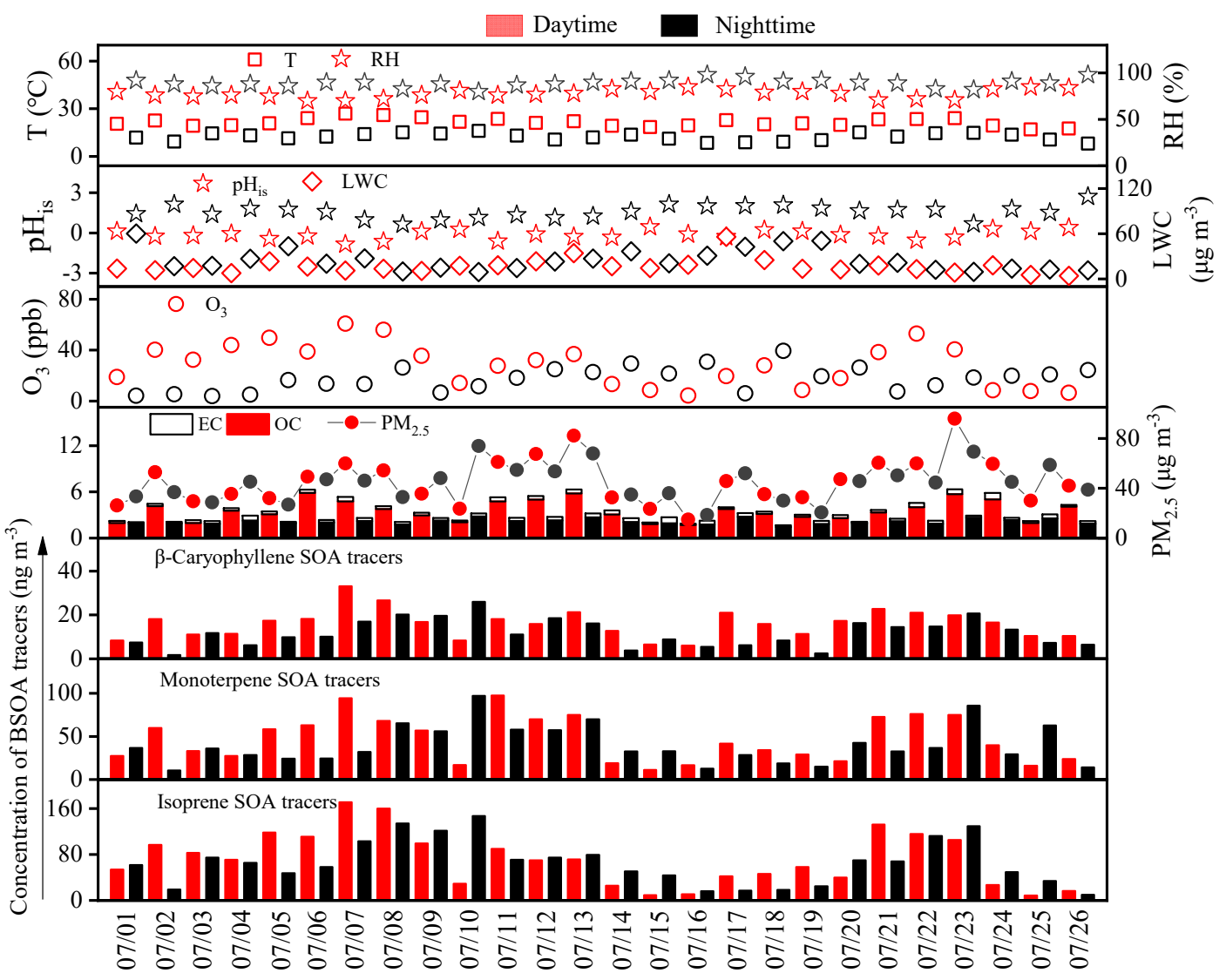

Fig. 3. Diurnal variations of temperature (T), relative humidity (RH), liquid water content (LWC) and in situ acidity of particles $\left(\mathrm{pH}_{\mathrm{is}}\right)$, the concentrations of $\mathrm{OC}$ and $\mathrm{EC}$ (organic and elemental carbon), $\mathrm{PM}_{2.5}$, biogenic secondary organic aerosols.

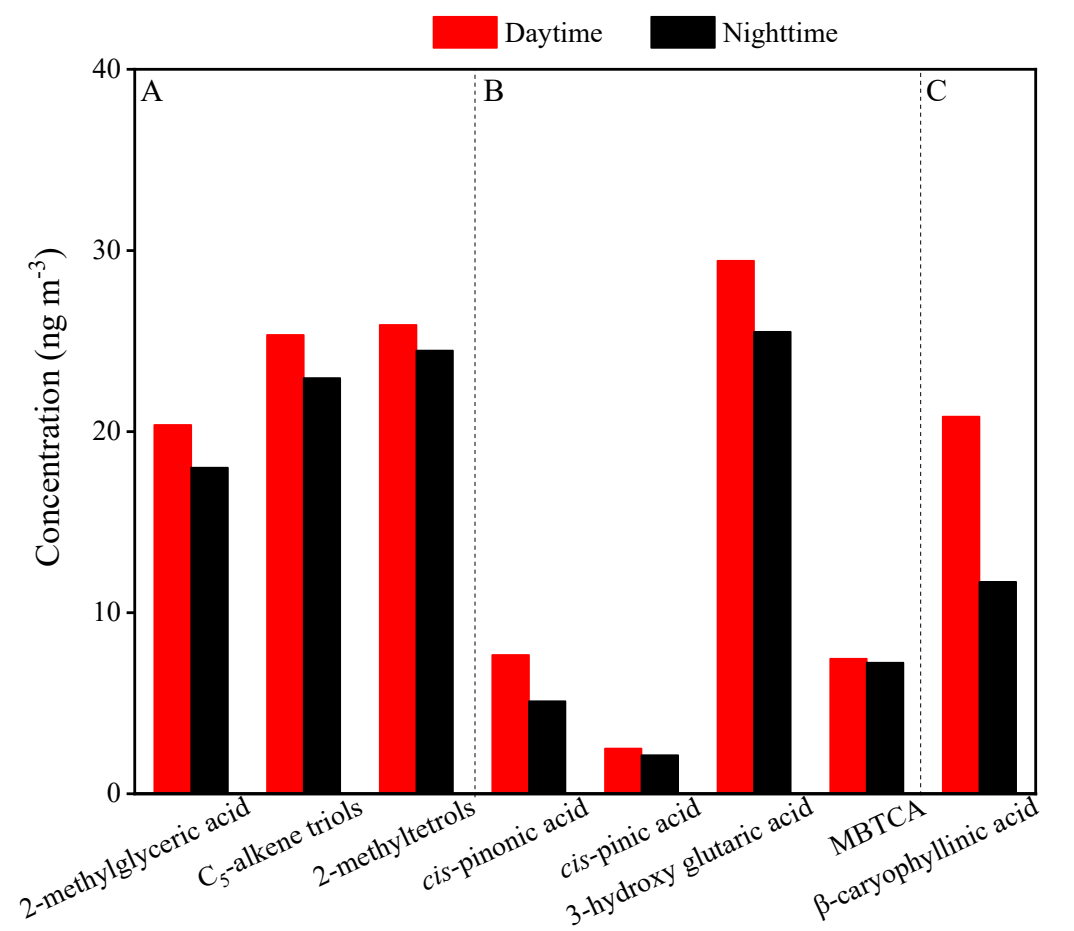

A: Isoprene SOA tracers B: Monoterpene SOA tracers $\quad$ : $\beta$-caryophyllene SOA tracers

Fig. 4. Diurnal variations of relative abundance of BSOA productions from Mt. Tai in summer ( ${ }^{a}$ MBTCA: 3-methyl-1,2,3butanetricarboxylic acid). 

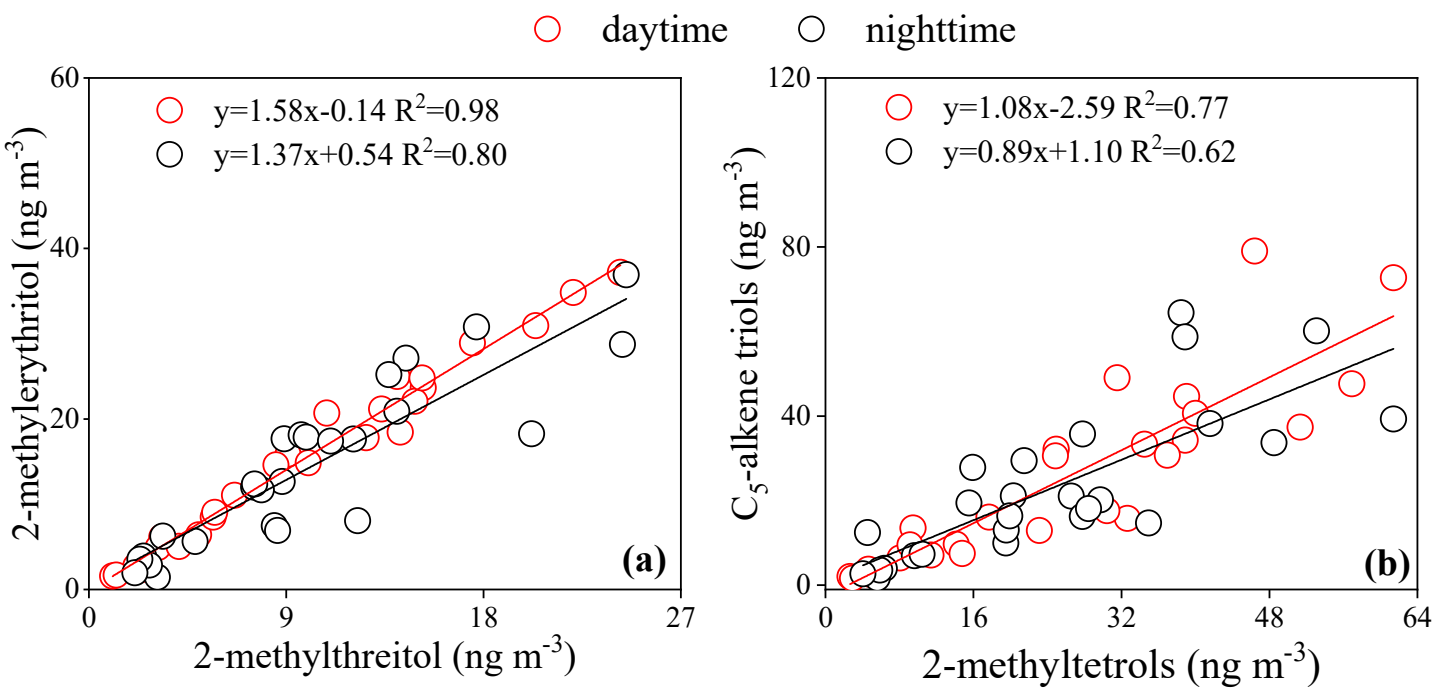

Fig. 5. Correlations between 2-methylthreitol and 2-methylerythritol, 2-methyltetrols and $\mathrm{C}_{5}$-alkene triols in Mt. Tai during summer.

summertime of 2016 and from other previous studies are shown in Table 3. In order to investigate the unique characteristics of aerosols at Mt. Tai in the summer, a comparison of chemical compositions of aerosols in highland, mountainous and urban regions was made. All BSOA tracers presented 14-26 times higher concentrations than those observed in the Qinghai Lake, China (Li et al., 2013b). However, the total concentrations of BSOA tracers in the summer of 2016 at Mt. Tai were about 1.4 times lower than those in $2006(\mathrm{Fu}$ et al., 2010). It is worth noting that the concentration levels of isoprene SOA tracers in this study were significantly lower than 10 years ago. Different meteorology factors between 2006 and 2016 may partially explain the decreased concentrations, as well as the different sampling periods.

As shown in Table 3, the total concentration of isoprene SOA tracers at Mt. Tai was about 1.4-1.9 times lower compared with some Chinese mountains such as Mt. Gongga in 2011 and Mt. Changbai in 2007 (Wang et al., 2008). Interestingly, the concentration levels of isoprene SOA tracers were observed to be almost equivalent to those reported in Mt. Fuji, Japan (Fu et al., 2014), mainly because the latitudes and altitudes of both sampling sites are similar and both mountains are dominated by the broadleaved forests (Meng et al., 2018). Furthermore, the $\mathrm{O}_{3}$ concentration at Mt. Tai in the whole sampling campaign is also comparable to that at Mt. Fuji increasing from a few ppb at night to about $60 \mathrm{ppb}$ at noon (Mochizuki et al., 2017), indicating that the oxidizing capacity at both sites during the observation periods is similar. Thus, the concentration of SOA tracers derived from isoprene were equal at these two mountainous regions. However, the total concentration of isoprene SOA tracers were higher than those in some Chinese mountains such as Mt. Wuyi (Ren et al., 2019), Mt. Hua (Li et al., 2013a) and Mt. Himalayas (Stone et al., 2012), and also higher than those observed in Chinese urban areas such as Shanghai (Zhu et al., 2018a), Xi'an (Ren et al., 2018) and Chengdu (Ren et al., 2018). The average concentrations of monoterpene SOA tracers at Mt. Tai $\left(43.5 \pm 24.4 \mathrm{ng} \mathrm{m}^{-3}\right)$ were comparable to those measured in Mt. Changbai (Wang et al., 2008) and Mt. Wuyi (Ren et al., 2019), China, and Mt. Fuji, Japan (Fu et al., 2014), and lower than Chinese urban areas (e.g., Xi' an and Chengdu) (Ren et al., 2018), but higher than Mt. Hua and Mt. Gongga, China (Li et al., 2013a; Li et al., 2018a). The concentration of $\beta$-caryophyllinic acid was comparable to those measured in Mt. Wuyi (Ren et al., 2019) and the Research Triangle Park, North Carolina, USA (11.5 $\mathrm{ng} \mathrm{m}^{-3}$ ) (Lewandowski et al., 2007), but was much higher than Ya'an, China (1.6 $\mathrm{ng} \mathrm{m}^{-3}$ ) (Li et al., 2013c); Okinawa Island, Japan (0.2 $\mathrm{ng} \mathrm{m}^{-3}$; Zhu et al., 2016); and Alaska, USA (0.62 $\mathrm{ng} \mathrm{m}^{-3}$; Haque et al., 2016).

\section{Effects of Meteorological Factors and Anthropogenic Pollutants on BSOA}

Temporal variations of BSOA tracers, meteorological factors and $\mathrm{O}_{3}$ concentration were present in Fig. 3. In this study, a significantly positive correlation $\left(R^{2}=0.58-0.86\right)$ of the mass concentrations of BSOA produced by isoprene $\left(\mathrm{SOA}_{i}\right)$, monoterpene $\left(\mathrm{SOA}_{\mathrm{m}}\right)$ and $\beta$-caryophyllene $\left(\mathrm{SOA}_{\mathrm{c}}\right)$ with $\mathrm{O}_{3}$ was observed for the daytime, respectively, but no clear linear correlation $\left(R^{2}<0.10\right)$ was found for the nighttime (Figs. 6(a)-6(c)). OH radicals (Fan and Zhang, 2004) and $\mathrm{O}_{3}$ (He et al., 2014) are major oxidants in the atmosphere reacted with the BVOCs in daytime, whereas the dominant oxidant is $\mathrm{NO}_{3}$ radicals in nighttime (Warneke et al., 2004). These results suggested that the daytime BSOA at the summit of Mt. Tai were largely produced by $\mathrm{O}_{3}$ and $\mathrm{OH}$ radical oxidation of BVOCs, while the nighttime BSOA might be derived from $\mathrm{NO}_{3}$ radical and other oxidizing agents $\left(\mathrm{H}_{2} \mathrm{O}_{2}\right)$ (Meng et al., 2018). In addition, the titration of $\mathrm{O}_{3}$ by the residual $\mathrm{NO}$ in the atmosphere at night can be proposed as an alternate explanation for the lack of correlation between BSOA tracers and $\mathrm{O}_{3}$ in nighttime (Edwards et al., 2017).

As shown in the Figs. 6(d)-6(f), the concentrations of $\mathrm{SOA}_{\mathrm{i}}, \mathrm{SOA}_{\mathrm{m}}$ and $\mathrm{SOA}_{\mathrm{c}}$ correlated strongly with temperature (T) $\left(R^{2} \geq 0.37\right)$ during daytime and nighttime, respectively, indicating that both the emissions of BVOCs and production of 
Table 3. Concentrations $\left(\mathrm{ng} \mathrm{m}^{-3}\right)$ of BSOA in Mt. Tai and other regions in the world during summer.

\begin{tabular}{|c|c|c|c|c|c|}
\hline Location & $\begin{array}{l}\text { Aerosols } \\
\text { type }\end{array}$ & $\begin{array}{l}\text { Isoprene } \\
\text { SOA tracers }\end{array}$ & $\begin{array}{l}\text { Monoterpene } \\
\text { SOA tracers }\end{array}$ & $\begin{array}{l}\beta \text {-caryophyllene } \\
\text { SOA tracers }\end{array}$ & Reference \\
\hline Mt. Tai, China & $\mathrm{PM}_{2.5}$ & 65.4 & 42.5 & 12.5 & This study \\
\hline Mt. Tai, China & TSP & 171 & 30 & 12 & (Fu et al., 2010) \\
\hline Qinghai Lake, China & $\mathrm{PM}_{2.5}$ & 2.5 & 3.0 & 0.9 & (Li et al., 2013b) \\
\hline Mt. Hua, China & $\mathrm{PM}_{10}$ & 13 & 6.6 & 2.2 & (Li et al., 2013a) \\
\hline Mt. Wuyi, China & $\mathrm{PM}_{2.5}$ & 21 & 36 & 11 & (Ren et al., 2019) \\
\hline Himalays, China & $\mathrm{PM}_{2.5}$ & 30.7 & 13.2 & 1.7 & (Stone et al., 2012) \\
\hline Mt. Fuji, Japan & TSP & 69 & 39 & 0.4 & (Fu et al., 2014) \\
\hline Mt. Gongga, China & $\mathrm{PM}_{2.5}$ & 89 & 3.6 & 0.13 & (Li et al., 2018a) \\
\hline Changbai, China & $\mathrm{PM}_{2.5}$ & 127 & 40 & $N A$ & (Wang et al., 2008) \\
\hline Shanghai, China & $\mathrm{PM}_{2.5}$ & 17.6 & 3.6 & 0.6 & (Zhu et al., 2018a) \\
\hline Xi'an, China & TSP & 20 & 58 & $N A$ & (Ren et al., 2018) \\
\hline Chengdu, China & TSP & 23 & 88 & $N A$ & (Ren et al., 2018) \\
\hline $\begin{array}{l}\text { Triangle Park, North } \\
\text { Carolina, USA }\end{array}$ & $\mathrm{PM}_{2.5}$ & $N A$ & $N A$ & 11.5 & (Lewandowski et al., 2007) \\
\hline Ya'an, China & $\mathrm{PM}_{2.5}$ & 71.1 & 5.8 & 1.6 & (Li et al., 2013c) \\
\hline Okinawa Island, Japan & TSP & 2.12 & 1.43 & 0.20 & (Zhu et al., 2016) \\
\hline Alaska, USA & TSP & 8.8 & 2.4 & 0.62 & (Haque et al., 2016) \\
\hline
\end{tabular}

${ }^{*} N A$ : not available.
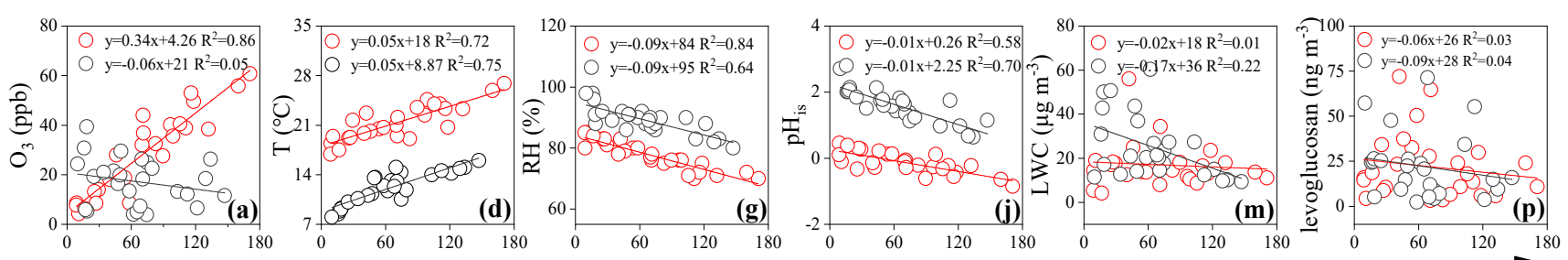

Total mass concentrations of isoprene SOA tracers $\left(\mathrm{SOA}_{\mathrm{i}}\right)\left(\mathrm{ng} \mathrm{m}^{-3}\right)$
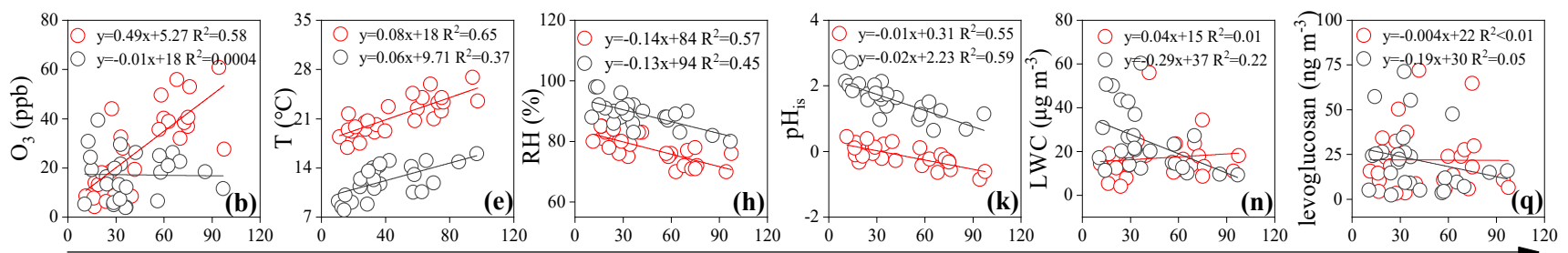

Total mass concentrations of monoterpene SOA tracers $\left(\mathrm{SOA}_{\mathrm{m}}\right)\left(\mathrm{ng} \mathrm{m}^{-3}\right)$
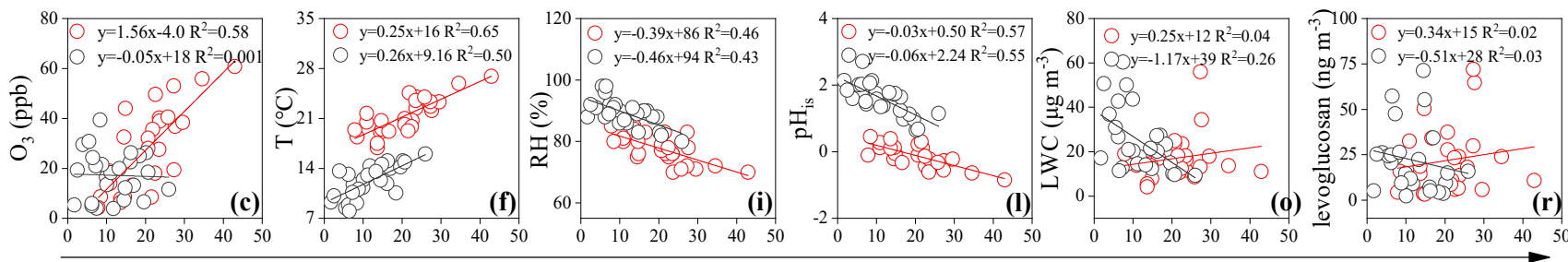

Total mass concentrations of $\beta$-caryophyllene SOA tracers $\left(\mathrm{SOA}_{\mathrm{c}}\right)\left(\mathrm{ng} \mathrm{m}^{-3}\right)$

Fig. 6. Linear regressions of $\mathrm{BSOA}$ tracers with $\mathrm{O}_{3}$, temperature $(T)$, relatively humidity $(\mathrm{RH})$, in situ $\mathrm{pH}\left(\mathrm{pH}_{\mathrm{is}}\right.$ ), liquid water content (LWC) and levoglucosan.

BSOA can be promoted under higher-temperature conditions (Meng et al., 2018; Yuan et al., 2018). The Arrhenius equation has demonstrated that high temperature can speed up the reaction rates (Ding et al., 2016). Such a phenomenon was also observed in other regions such as Qinghai Lake ( $\mathrm{Li}$ et al., 2013b), Mt. Wuyi (Ren et al., 2019) and Mt. Hua in
China (Li et al., 2013a), and Germany (Zhang et al., 2010). Temperature measured at the summit of Mt. Tai during the sampling time only indicates the local weather conditions rather than the regional meteorological conditions. Thus, significant correlations between BSOA tracers and temperature can only be found when BSOA are mostly originated from 
the local oxidation of BVOCs emissions rather than longdistance transport. In addition, the higher $\mathrm{O}_{3}$ concentration in the daytime suggested that oxidation potential was stronger at the top of Mt. Tai during the daytime than during the nighttime. Trees are the only emission of isoprene in daytime. Therefore, the higher concentrations of BSOA tracers in daytime can be explained by the stronger photochemical oxidation and enhancements in BVOCs emissions. In this study, the concentration of BSOA tracers showed a significant negative correlation with RH $\left(R^{2} \geq 0.43\right)$ (Figs. 6(g)-6(i)) in daytime and nighttime, respectively. Chamber experiment (Zhang et al., 2011) and field measurements (Li et al., 2013a; Ren et al., 2019) have demonstrated that lower-RH conditions can favor the formation of BSOA from isoprene and other BVOCs by the photochemical oxidation. In contrast, 2-methyltetrols did not change dramatically as $\mathrm{RH}$ varied (Riva et al., 2016). Moreover, a strong negative correlation was also observed for BSOA tracers and $\mathrm{pH}_{\text {is }}\left(R^{2} \geq 0.55\right)$ (Figs. 6(i)-6(1)) in the whole sampling campaign, suggesting that the acidic condition is favorable for the formation of BSOA and their precursors. Previous studies pointed that aerosol acidity can promote the formation of BSOA derived from the acid-catalyzed heterogeneous oxidation BVOCs (Ding et al., 2011; Li et al., 2013a). Nguyen et al. (2011) reported that the increased RH was the foremost factors controlling the BSOA formation, mainly attributed to the suppression of condensation and addition reactions such as hemiacetal formation and aldol formation. High RH conditions can restrain the acid-catalyzed formation of BSOA because of the dilution of aerosol acidity (Li et al., 2013a). Therefore, BSOA negatively correlated with both $\mathrm{RH}$ and $\mathrm{pH}_{\mathrm{is}}$.

$\mathrm{RH}$ and aerosol hygroscopic composition are key factors controlling the aerosol LWC (Bikkina et al., 2017). However, the total concentration of $\mathrm{SOA}_{i}, \mathrm{SOA}_{m}$ and $\mathrm{SOA}_{\mathrm{c}}$ did not show any correlation with $\mathrm{LWC}$ in daytime and nighttime, respectively (Figs. 6(m)-6(o)). The higher LWC can promote the partitioning of water-soluble semi-volatile organic precursors of BSOA into the aqueous phase, and further improves the formation of BSOA (McNeill et al., 2012). Nevertheless, LWC can reduce particle acidity, which suppresses the formation of BSOA via acid-catalyzed reactions (Riva et al., 2016). Thus, there was no correlation between LWC and the concentration of $\mathrm{SOA}_{i}, \mathrm{SOA}_{m}$ and $\mathrm{SOA}_{c}$ in the aerosols of Mt. Tai. Furthermore, there was no correlation between BSOA tracers and anthropogenic pollutants such as levoglucosan, $\mathrm{SO}_{4}{ }^{2-}, \mathrm{NO}_{3}{ }^{-}$and $\mathrm{EC}$ during daytime and nighttime, respectively (Figs. 6(p)-6(r), Table S1), which is consistent with our discussions above. Such a phenomenon was also observed in Mt. Hua, China, where the effect of anthropogenic pollutants was no significant correlation in summer (Li et al., 2013a). Levoglucosan was acknowledged as a remarkable tracer of biomass burning, which formed by hemicellulose and the pyrolysis of cellulose (Fu et al., 2016). In this work, no correlation $\left(R^{2} \leq 0.05\right)$ was found between BSOA tracers and levoglucosan during the whole sampling campaign, indicating the effect of biomass burning on the formation of BSOA is minor. Previous study has observed that biomass burning (filed burning of wheat straws) was mainly performed during May to June in the
North China Plain (Fu et al., 2012). The observation campaign in this study was conducted in July when the field burning of wheat straw residue was rarely observed. Therefore, BSOA tracers did not show any correlation with levoglucosan at Mt. Tai, clearly suggesting that the BSOA formation was mostly originated from the oxidation of BVOCs rather than biomass burning.

Consequently, these results clearly demonstrated that BSOA derived from isoprene, monoterpene and $\beta$-caryophyllene in the summertime atmosphere of Mt. Tai during the campaign were mostly originated from the local oxidation of BVOCs rather than the anthropogenic emissions from the lowlands by long-distance transport. Such a conclusion highlighted the important role of the BVOCs emissions in the formation process of BSOA in the forested highland region when the emission of BVOCs was dominant in the summertime atmosphere of Mt. Tai.

\section{CONCLUSIONS}

The profiles of eleven kinds of BSOA tracers derived from isoprene, monoterpene and $\beta$-caryophyllene in $\mathrm{PM}_{2.5}$ samples from the top of Mt. Tai (1534 m a.s.l.) during the summer, along with the EC, OC, WSOC, levoglucosan and inorganic ions, were determined. The average concentrations of the isoprene, monoterpene and $\beta$-caryophyllene oxidation products were $68.5 \pm 42.6 \mathrm{ng} \mathrm{m}^{-3}, 43.5 \pm 24.4 \mathrm{ng} \mathrm{m}^{-3}$ and $16.3 \pm 8.6 \mathrm{ng} \mathrm{m}^{-3}$, respectively. The concentrations were almost 1.4 times lower than those recorded in 2006, which were influenced by biomass burning, but equal to those observed on Mt. Fuji, Japan, due to the similarity in latitude, altitude and vegetation type. The concentrations of all of the BSOA tracers were higher during the day than at night, suggesting that the higher diurnal temperatures and solar radiation favored the emission of BVOCs and formation of BSOA. The concentrations of the BSOA tracers and $\mathrm{O}_{3}$ displayed significantly positive correlations during the daytime, but no clear linear correlation was found for nighttime. The temperature was positively correlated with all of the BSOA tracers over the whole campaign, as higher temperatures can promote BVOCs emission and BSOA formation. Conversely, $\mathrm{RH}$ and $\mathrm{pH}_{\mathrm{is}}$ exhibited significantly negative correlations with the concentrations of the BSOA tracers during the daytime and nighttime because higher $\mathrm{RH}$ can reduce the in situ particle acidity, which further suppresses the effect of acid catalysis on BSOA formation. However, the concentrations of the BSOA tracers did not show any correlation with the LWC regardless of the time. Moreover, no significant linear correlation between the BSOA tracers and anthropogenic pollutants, such as levoglucosan, $\mathrm{SO}_{4}{ }^{2-}$, $\mathrm{NO}_{3}{ }^{-}$and $\mathrm{EC}$, was observed over the entire observation period, which indicates that BSOA in the typical summertime atmosphere of Mt. Tai mainly originates from the local oxidation of BVOCs rather than long-range-transported anthropogenic pollutants.

\section{ACKNOWLEDGMENTS}

This work was supported by China National Science 
Funds (Grant No. 41505112 and 41702373), Natural Science Foundation of Shandong Province (Grant No. BS2015HZ002) and Open Funds of State Key Laboratory of Loess and Quaternary Geology, Institute of Earth Environment, Chinese Academy of Sciences (Grant Nos. SKLLQG1509 and SKLLQG1504).

\section{SUPPLEMENTARY MATERIAL}

Supplementary data associated with this article can be found in the online version at http://www.aaqr.org.

\section{REFERENCES}

An, Z., Huang, R.J., Zhang, R., Tie, X., Li, G., Cao, J., Zhou, W., Shi, Z., Han, Y., Gu, Z. and Ji, Y. (2019). Severe haze in northern China: A synergy of anthropogenic emissions and atmospheric processes. Proc. Natl. Acad. Sci. U.S.A. 116: 8657-8666.

Bikkina, S., Kawamura, K. and Sarin, M. (2017). Secondary organic aerosol formation over coastal ocean: Inferences from atmospheric water-soluble low molecular weight organic compounds. Environ. Sci. Technol. 51: 43474357.

Chow, J.C., Watson, J.G., Chen, L.W.A., Arnott, W.P., Moosmüller, H. and Fung, K. (2004). Equivalence of elemental carbon by thermal/optical reflectance and transmittance with different temperature protocols. Environ. Sci. Technol. 38: 4414-4422.

Claeys, M., Graham, B., Vas, G., Wang, W., Vermeylen, R., Pashynska, V., Cafmeyer, J., Guyon, P., Andreae, M.O., Artaxo, P. and Maenhaut, W. (2004). Formation of secondary organic aerosols through photooxidation of isoprene. Science 303: 1173-1176.

Ding, X., Wang, X.M. and Zheng, M. (2011). The influence of temperature and aerosol acidity on biogenic secondary organic aerosol tracers: Observations at a rural site in the central Pearl River Delta region, South China. Atmos. Environ. 45: 1303-1311.

Ding, X., Wang, X.M., Gao, B., Fu, X.X., He, Q.F., Zhao, X.Y., Yu, J.Z. and Zheng, M. (2012). Tracer-based estimation of secondary organic carbon in the Pearl River Delta, South China. J. Geophys. Res. 117: D05313.

Ding, X., He, Q.F., Shen, R.Q., Yu, Q.Q., Zhang, Y.Q., Xin, J.Y., Wen, T.X. and Wang, X.M. (2016). Spatial and seasonal variations of isoprene secondary organic aerosol in China: Significant impact of biomass burning during winter. Sci. Rep. 6: 20411.

Duhl, T.R., Helmig, D. and Guenther, A. (2008). Sesquiterpene emissions from vegetation: A review. Biogeosciences 5: 761-777.

Edwards, P.M., Aikin, K.C., Dube, W.P., Fry, J.L., Gilman, J.B., de Gouw, J.A., Graus, M.G., Hanisco, T.F., Holloway, J., Hübler, G., Kaiser, J., Keutsch, F.N., Lerner, B.M., Neuman, J.A., Parrish, D.D., Peischl, J., Pollack, I.B., Ravishankara, A.R., Roberts, J.M., Ryerson, T.B., Trainer, M., Veres, P.R., Wolfe, G.M., Warneke, C. and Brown, S.S. (2017). Transition from high- to low- $\mathrm{NO}_{\mathrm{x}}$ control of night-time oxidation in the Southeastern US.
Nat. Geosci. 10: 490-495.

Fan, J. and Zhang, R. (2004). Atmospheric oxidation mechanism of isoprene. Environ. Chem. 1: 140-149.

Fang, C., Zhang, Z., Jin, M., Zou, P. and Wang, J. (2017). Pollution characteristics of $\mathrm{PM}_{2.5}$ aerosol during haze periods in Changchun, China. Aerosol Air Qual. Res. 17: 888-895.

Fu, P., Kawamura, K., Okuzawa, K., Aggarwal, S.G., Wang, G., Kanaya, Y. and Wang, Z. (2008). Organic molecular compositions and temporal variations of summertime mountain aerosols over Mt. Tai, North China Plain. $J$. Geophys. Res. 113: D19107.

Fu, P., Kawamura, K., Chen, J. and Barrie, L.A. (2009). Isoprene, monoterpene, and sesquiterpene oxidation products in the high Arctic aerosols during late winter to early summer. Environ. Sci. Technol. 43: 4022-4028.

Fu, P., Kawamura, K., Kanaya, Y. and Wang, Z. (2010). Contributions of biogenic volatile organic compounds to the formation of secondary organic aerosols over Mt Tai, Central East China. Atmos. Environ. 44: 4817-4826.

Fu, P., Kawamura, K. and Miura, K. (2011). Molecular characterization of marine organic aerosols collected during a round-the-world cruise. J. Geophys. Res. 116: D13302.

Fu, P., Kawamura, K., Chen, J. and Miyazaki, Y. (2014). Secondary production of organic aerosols from biogenic VOCs over Mt. Fuji, Japan. Environ. Sci. Technol. 48: 8491-8497.

Fu, P., Zhuang, G., Sun, Y., Wang, Q., Chen, J., Ren, L., Yang, F., Wang, Z., Pan, X., Li, X. and Kawamura, K. (2016). Molecular markers of biomass burning, fungal spores and biogenic soa in the taklimakan desert aerosols. Atmos. Environ. 130: 64-73.

Fu, P.Q., Kawamura, K., Chen, J., Li, J., Sun, Y.L., Liu, Y., Tachibana, E., Aggarwal, S.G., Okuzawa, K., Tanimoto, H., Kanaya, Y. and Wang, Z.F. (2012). Diurnal variations of organic molecular tracers and stable carbon isotopic compositions in atmospheric aerosols over Mt. Tai in North China Plain: An influence of biomass burning. Atmos. Chem. Phys. 12: 8359-8375.

Guenther, A., Karl, T., Harley, P., Wiedinmyer, C., Palmer, P.I. and Geron, C. (2006). Estimates of global terrestrial isoprene emissions using MEGAN (model of emissions of gases and aerosols from nature). Atmos. Chem. Phys. 6: 3181-3210.

Han, Y., Iwamoto, Y., Nakayama, T., Kawamura, K. and Mochida, M. (2014). Formation and evolution of biogenic secondary organic aerosol over a forest site in Japan. $J$. Geophys. Res. 119: 259-273.

Haque, M.M., Kawamura, K. and Kim, Y. (2016). Seasonal variations of biogenic secondary organic aerosol tracers in ambient aerosols from Alaska. Atmos. Environ. 130: 95-104.

He, N., Kawamura, K., Okuzawa, K., Pochanart, P., Liu, Y., Kanaya, Y. and Wang, Z.F. (2014). Diurnal and temporal variations of water-soluble dicarboxylic acids and related compounds in aerosols from the northern vicinity of Beijing: Implication for photochemical aging during atmospheric transport. Sci. Total Environ. 499: 154-165. 
Hegde, P. and Kawamura, K. (2012). Seasonal variations of water-soluble organic carbon, dicarboxylic acids, ketocarboxylic acids, and $\alpha$-dicarbonyls in central Himalayan aerosols. Atmos. Chem. Phys. 12: 6645-6665.

Hong, Z., Zhang, H., Zhang, Y., Xu, L., Liu, T., Xiao, H., Hong, Y., Chen, J., Li, M., Deng, J., Wu, X., Hu, B. and Chen, X. (2019). Secondary organic aerosol of $\mathrm{PM}_{2.5}$ in a mountainous forest area in southeastern China: Molecular compositions and tracers implication. Sci. Total Environ. 653: 496-503.

Hu, B., Xu, H., Deng, J., Yi, Z., Chen, J., Xu, L., Hong, Z., Chen, X. and Hong, Y. (2018). Characteristics and source apportionment of volatile organic compounds for different functional zones in a coastal city of southeast China. Aerosol Air Qual. Res. 18: 2840-2852.

Hu, D., Bian, Q.J., Li, T.W.Y., Lau, A.K.H. and Yu, J.Z. (2008). Contributions of isoprene, monoterpenes, $\beta$ caryophyllene, and toluene to secondary organic aerosols in Hong Kong during the summer of 2006. J. Geophys. Res. 113: D22206.

Hu, Q.H., Xie, Z.Q., Wang, X.M., Kang, H., He, Q.F. and Zhang, P. (2013). Secondary organic aerosols over oceans via oxidation of isoprene and monoterpenes from Arctic to Antarctic. Sci. Rep. 3: 2280.

Huang, R.J., Zhang, Y., Bozzetti, C., Ho, K.F., Cao, J.J., Han, Y., Daellenbach, K.R., Slowik, J.G., Platt, S.M., Canonaco, F., Zotter, P., Wolf, R., Pieber, S.M., Bruns, E.A., Crippa, M., Ciarelli, G., Piazzalunga, A., Schwikowski, M., Abbaszade, G., Schnelle-Kreis, J., Zimmermann, R., An, Z., Szidat, S., Baltensperger, U., El Haddad, I. and Prevot, A.S. (2014). High secondary aerosol contribution to particulate pollution during haze events in China. Nature 514: 218-222.

Jaoui, M., Lewowski, M., Kleindienst, T.E., Offenberg, J.H. and Edney, E.O. (2007) $\beta$-Caryophyllinic acid: an atmospheric tracer for $\beta$-caryophyllene secondary organic aerosol. Geophys. Res. Lett. 34: L05816.

Jiang, N., Guo, Y., Wang, Q., Kang, P., Zhang, R. and Tang, X. (2017). Chemical composition characteristics of $\mathrm{PM}_{2.5}$ in three cities in He'nan, central China. Aerosol Air Qual. Res. 17: 2367-2380.

Kesselmeier, J. and Staudt, M. (1999). Biogenic volatile organic compounds (VOC): An overview on emission, physiology and ecology. J. Atmos. Chem. 33: 23-88.

Lewandowski, M., Jaoui, M., Kleindienst, T.E., Offenberg, J.H. and Edney, E.O. (2007). Composition of $\mathrm{PM}_{2.5}$ during the summer of 2003 in research Triangle Park, North Carolina. Atmos. Environ. 41: 4073-4083.

Li, J.J., Wang, G.H., Cao, J.J., Wang, X.M. and Zhang, R.J. (2013a). Observation of biogenic secondary organic aerosols in the atmosphere of a mountain site in central China: Temperature and relative humidity effects. Atmos. Chem. Phys. 13: 11535-11549.

Li, J.J., Wang, G.H., Wang, X.M., Cao, J.J., Sun, T., Cheng, C.L., Meng, J.J., Hu, T.F. and Liu, S.X. (2013b). Abundance, composition and source of atmospheric $\mathrm{PM}_{2.5}$ at a remote site in the Tibetan Plateau, China. Tellus B 65: 20281.

Li, L., Dai, D., Deng, S., Feng, J., Zhao, M., Wu, J., Liu, L.,
Yang, X., Wu, S., Qi, H., Yang, G., Zhang, X., Wang, Y. and Zhang, Y. (2013c). Concentration, distribution and variation of polar organic aerosol tracers in Ya'an, a middle-sized city in western China. Atmos. Res. 120-121: 29-42.

Li, L., Lai, W., Pu, J., Mo, H., Dai, D., Wu, G. and Deng, S. (2018a). Polar organic tracers in $\mathrm{PM}_{2.5}$ aerosols from an inland background area in southwest China: Correlations between secondary organic aerosol tracers and source apportionment. J. Environ. Sci. (China) 69: 281-293.

Li, Y.C., Shu, M., Ho, S.S.H., Yu, J.Z., Yuan, Z.B., Wang, X.X., Zhao, X.Q. and Liu, Z.F. (2018b). Effects of chemical composition of $\mathrm{PM}_{2.5}$ on visibility in a semirural city of Sichuan basin. Aerosol Air Qual. Res. 18: 957-968.

Liu, X., Meng, J., Hou, Z., Yan, L., Wang, G., Yi, Y., Wei, B., Fu, M., Li, J. and Cao, J. (2019). Molecular compositions and sources of organic aerosols from urban atmosphere in the North China Plain during the wintertime of 2017. Aerosol Air Qual. Res. 19: 2267-2280.

McNeill, V.F., Woo, J.L., Kim, D.D., Schwier, A.N., Wannell, N.J., Sumner, N.J. and Barakat, J.M. (2012). Aqueous-phase secondary organic aerosol and organosulfate formation in atmospheric aerosols a modeling study. Environ. Sci. Technol. 46: 8075-8081.

Meng, C.C., Wang, L.T., Zhang, F.F., Wei, Z., Ma, S.M., Ma, $X$. and Yang, J. (2016). Characteristics of concentrations and water-soluble inorganic ions in $\mathrm{PM}_{2.5}$ in Handan city, Hebei province, China. Atmos. Res. 171: 133-146.

Meng, J., Wang, G., Li, J., Cheng, C., Ren, Y., Huang, Y., Cheng, Y., Cao, J. and Zhang, T. (2014). Seasonal characteristics of oxalic acid and related SOA in the free troposphere of Mt. Hua, central China: Implications for sources and formation mechanisms. Sci. Total Environ. 493: 1088-1097.

Meng, J., Wang, G., Hou, Z., Liu, X., Wei, B., Wu, C., Cao, C., Wang, J., Li, J., Cao, J., Zhang, E., Dong, J., Liu, J., Ge, S. and Xie, Y. (2018). Molecular distribution and stable carbon isotopic compositions of dicarboxylic acids and related SOA from biogenic sources in the summertime atmosphere of Mt. Tai in the North China Plain. Atmos. Chem. Phys. 18: 15069-15086.

Mochizuki, T., Kawamura, K., Miyazaki, Y., Wada, R., Takahashi, Y., Saigusa, N. and Tani, A. (2017). Secondary formation of oxalic acid and related organic species from biogenic sources in a larch forest at the northern slope of Mt. Fuji. Atmos. Environ. 166: 255-262.

Nguyen, T.B., Roach, P.J., Laskin, J., Laskin, A. and Nizkorodov, S.A. (2011). Effect of humidity on the composition of isoprene photooxidation secondary organic aerosol. Atmos. Chem. Phys. 11: 6931-6944.

Priyadharshini, B., Verma, S., Chatterjee, A., Sharma, S.K. and Mandal, T.K. (2019). Chemical characterization of fine atmospheric particles of water-soluble ions and carbonaceous species in a tropical urban atmosphere over the eastern Indo-Gangetic Plain. Aerosol Air Qual. Res. 19: 129-147.

Ren, Y., Wang, G., Li, J., Wu, C., Cao, C., Wang, J., Zhang, L., Meng, F. and Li, H. (2018). Seasonal variation and 
size distribution of biogenic secondary organic aerosols at urban and continental background sites of China. $J$. Environ. Sci. (China) 71: 32-44.

Ren, Y., Wang, G., Tao, J., Zhang, Z., Wu, C., Wang, J., Li, J., Wei, J., Li, H. and Meng, F. (2019). Seasonal characteristics of biogenic secondary organic aerosols at Mt. Wuyi in southeastern China: Influence of anthropogenic pollutants. Environ. Pollut. 252: 493-500.

Riva, M., Bell, D.M., Hansen, A.M.K., Drozd, G.T., Zhang, Z. and Gold, A. (2016). Effect of organic coatings, humidity and aerosol acidity on multiphase chemistry of isoprene epoxydiols. Environ. Sci. Technol. 50: 5580-5588.

Stone, E.A., Nguyen, T.T., Pradhan, B.B. and Man Dangol, P. (2012). Assessment of biogenic secondary organic aerosol in the Himalayas. Environ. Chem. 9: 263-272.

Surratt, J.D., Murphy, S.M., Kroll, J.H., Ng, N.L., Hildebrandt, L., Sorooshian, A., Szmigielski, R., Vermeylen, R., Maenhaut, W., Claeys, M., Flagan, R.C. and Seinfeld, J.H. (2006). Chemical composition of secondary organic aerosol formed from the photooxidation of isoprene. $J$. Phys. Chem. A 110: 9665-9690.

Szmigielski, R., Surratt, J.D., Gómez-González, Y., Van der Veken, P., Kourtchev, I., Vermeylen, R., Blockhuys, F., Jaoui, M., Kleindienst, T.E., Lewandowski, M., Offenberg, J.H., Edney, E.O., Seinfeld, J.H., Maenhaut, W. and Claeys, M. (2007). 3-methyl-1,2,3-butanetricarboxylic acid: An atmospheric tracer for terpene secondary organic aerosol. Geophys. Res. Lett. 34: L24811.

Verma, N., Satsangi, A., Lakhani, A. and Kumari, K.M. (2017). Low molecular weight monocarboxylic acids in $\mathrm{PM}_{2.5}$ and $\mathrm{PM}_{10}$ : Quantification, seasonal variation and source apportionment. Aerosol Air Qual. Res. 17: 485498.

Wang, G.H. and Kiawamura, K. (2006). Molecular, seasonal, and spatial distributions of organic aerosols from fourteen Chinese cities. Environ. Sci. Technol. 40: 4619-4625.

Wang, G., Kawamura, K., Xie, M., Hu, S., Gao, S., Cao, J., An, Z. and Wang, Z. (2009). Size-distributions of $n$ alkanes, pahs and hopanes and their sources in the urban, mountain and marine atmospheres over East Asia. Atmos. Chem. Phys. 9: 8869-8882.

Wang, W., Wu, M.H., Li, L., Zhang, T., Liu, X.D., Feng, J.L., Feng, H.J., Wang, Y.J., Sheng, G.Y., Claeys, M. and Fu, J.M. (2008). Polar organic tracers in $\mathrm{PM}_{2.5}$ aerosols from forests in eastern China. Atmos. Chem. Phys. 8: 7507-7518.

Warneke, C., de Gouw, J.A., Goldan, P.D., Kuster, W.C., Williams, E.J., Lerner, B.M., Jakoubek, R., Brown, S.S., Stark, H., Aldener, M., Ravishankara, A.R., Roberts, J.M., Marchewka, M., Bertman, S., Sueper, D.T., McKeen, S.A., Meagher, J.F. and Fehsenfeld, F.C. (2004). Comparison of daytime and nighttime oxidation of biogenic and anthropogenic VOCs along the New
England coast in summer during new england air quality study 2002. J. Geophys. Res. 109: D10309.

Wu, X., Deng, J., Chen, J., Hong, Y., Xu, L., Yin, L., Du, W., Hong, Z., Dai, N. and Yuan, C.S. (2017). Characteristics of water-soluble inorganic components and acidity of $\mathrm{PM}_{2.5}$ in a coastal city of China. Aerosol Air Qual. Res. 17: 2152-2164.

Xu, L., Pye, H.O.T., He, J., Chen, Y., Murphy, B.N. and Ng, N.L. (2018). Large contributions from biogenic monoterpenes and sesquiterpenes to organic aerosol in the southeastern United States. Atmos. Chem. Phys. Discuss. https://doi.org/10.5194/acp-2017-1109.

Yuan, Q., Lai, S., Song, J., Ding, X., Zheng, L., Wang, X., Zhao, Y., Zheng, J., Yue, D., Zhong, L., Niu, X. and Zhang, Y. (2018). Seasonal cycles of secondary organic aerosol tracers in rural Guangzhou, southern China: The importance of atmospheric oxidants. Environ. Pollut. 240: 884-893.

Zhang, H., Surratt, J.D., Lin, Y.H., Bapat, J. and Kamens, R.M. (2011). Effect of relative humidity on SOA formation from isoprene/no photooxidation: Enhancement of 2-methylglyceric acid and its corresponding oligoesters under dry conditions. Atmos. Chem. Phys. 11: 6411-6424.

Zhang, Y., Müller, L., Winterhalter, R., Moortgat, G.K., Hoffmann, T. and Pöschl, U. (2010). Seasonal cycle and temperature dependence of pinene oxidation products, dicarboxylic acids and nitrophenols in fine and coarse air particulate matter. Atmos. Chem. Phys. 10: 7859-7873.

Zhu, C., Kawamura, K. and Fu, P. (2016). Seasonal variations of biogenic secondary organic aerosol tracers in Cape Fedo, Okinawa. Atmos. Environ. 130: 113-119.

Zhu, W., Luo, L., Cheng, Z., Yan, N., Lou, S. and Ma, Y. (2018a). Characteristics and contributions of biogenic secondary organic aerosol tracers to $\mathrm{PM}_{2.5}$ in Shanghai, China. Atmos. Pollut. Res. 9: 179-188.

Zhu, Y., Yang, L., Kawamura, K., Chen, J., Ono, K., Wang, X., Xue, L. and Wang, W. (2017). Contributions and source identification of biogenic and anthropogenic hydrocarbons to secondary organic aerosols at Mt. Tai in 2014. Environ. Pollut. 220: 863-872.

Zhu, Y., Yang, L., Chen, J., Kawamura, K., Sato, M., Tilgner, A., van Pinxteren, D., Chen, Y., Xue, L., Wang, X., Simpson, I.J., Herrmann, H., Blake, D.R. and Wang, W. (2018b). Molecular distributions of dicarboxylic acids, oxocarboxylic acids and $\alpha$-dicarbonyls in $\mathrm{PM}_{2.5}$ collected at the top of Mt. Tai, north China, during the wheat burning season of 2014. Atmos. Chem. Phys. 18: 10741-10758.

Received for review, October 18, 2019 Revised, November 5, 2019 Accepted, November 8, 2019 